\section{Using Near Infrared Reflectance Spectroscopy to Evaluate Phosphorus, Potassium, Calcium, and Magnesium Concentrations in Bermudagrass}

\author{
Grady L. Miller ${ }^{1}$ and Adam Thomas \\ Department of Environmental Horticulture, University of Florida, Gainesville, \\ FL 32611-0670 \\ Additional index words. Cynodon dactylon $\mathrm{x}$ C. transvaalensis, turfgrass nutrition, \\ fertilization
}

\begin{abstract}
Application of nutrients to correct nutrient deficiencies in turfgrasses are often based on tissue analysis. Previous research has indicated that near infrared reflectance spectroscopy (NIRS) may be useful in tissue nutrient concentration determination since it requires minimum sample preparation and has been a reliable predictor of $\mathrm{N}$ concentration. The objective of this study was to evaluate the reliability of NIRS in determining $\mathrm{P}, \mathrm{K}, \mathrm{Ca}$, and $\mathrm{Mg}$ concentrations in bermudagrass [Cynodon dactylon (L.) Pers. $\mathrm{X}$ C. transvaalensis Burtt Davy]. Tissue samples were collected from Florida golf courses, representing different cultivars grown under various conditions and fertilizer regimes. Tissue samples were analyzed using NIRS and traditional wet chemistry (Mehlich-1 extracts analyzed using inductively coupled argon spectrophotometer) before results were statistically compared. Results from wet chemistry analysis averaged $15 \%$ lower than those obtained from NIRS. Although results for certain cultivars and elements were positively correlated ('Tifdwarf' Ca, $\boldsymbol{r}^{2}=0.72 ; P<0.01$ ), precision across all cultivars and nutrients was not sufficient (accounted for only $26 \%$ of variability) to indicate that NIRS would be an effective management tool for the elements evaluated in this study.
\end{abstract}

Near infrared reflectance spectroscopy (NIRS) is a nondestructive method, which can rapidly analyze the chemical composition of materials with little sample preparation. Analysis is based on the principle that each element has its own distinct near infrared absorption properties which can be measured (Marten et al., 1985). NIRS technology has been used for over 30 years in the forage industry measuring forage compositions such as acid detergent fiber, neutral detergent fiber, dry matter, and lignin content (Marten et al., 1985). Research has shown NIRS can accurately predict the response of corn (Zea mays L.) to fertilizer and $\mathrm{N}$-supplying capability of the soil (Fox et al., 1993). NIRS has proven reliable in predicting $\mathrm{P}, \mathrm{K}$, and $\mathrm{Ca}$ content in forages $\left(r^{2}>0.74\right)$ (Clark et al., 1987). Recently NIRS research has been directed towards turfgrass nutrient analysis. Murphy (1993) concluded NIRS has potential as a rapid and none subjective method of predicting $\mathrm{N}$ content of perennial ryegrass (Lolium perenne L.) $\left(r^{2}=0.93\right)$ and creeping bentgrass (Agrostis palustris L.) $\left(r^{2}=0.89\right)$. A study at the Univ. of Florida indicated NIRS could accurately predict $\mathrm{N}$ content in 'FloraDwarf' and 'Tifdwarf' bermudagrass [Cynodon dactylon (L.) Pers.

Received for publication 20 May 2002. Accepted for publication 2 Dec. 2002. Journal Paper no. R08841, Florida Agriculture Experiment Station. The authors would like to thank the Toro Corporation for funding this research and assisting in the collection of samples from south Florida.

'e-mail GMiller@mail.ifas.ufl.edu

HortScience, Vol. 38(6), October 2003
Although $\mathrm{P}, \mathrm{K}, \mathrm{Ca}$, and $\mathrm{Mg}$ are essential nutrients for plant growth, when applied in excessive amounts they may cause deficiencies in other elements. Cations such as $\mathrm{K}$, $\mathrm{Ca}$, and $\mathrm{Mg}$ can alter the uptake of other ions. Potassium is a monovalent cation and is absorbed more rapidly by the plant and to a greater degree than divalent cations such as $\mathrm{Ca}$ and $\mathrm{Mg}$. High application rates of $\mathrm{K}$ have been shown to be associated with decreased soil extractable $\mathrm{Ca}$ and $\mathrm{Mg}$, which results in tissue deficiencies of these nutrients (Miller, 1999). Bermudagrass growth can be hindered by excessive $P$ applications due to a decrease in Nuptake (Sartain and Dudeck, 1982). Research has also indicated a reduction in plant available $\mathrm{K}$ due to over-application of $\mathrm{P}$ (Nus et al., 1993). If applied to turfgrass inappropriately, phosphorus can potentially damage surface water. Surface runoff containing $P$ can cause eutrophication. As eutrophication occurs, algae and weeds grow rapidly creating an unhealthy environment for fish and other aquatic organisms and make water unsuitable for drinking (Brady and Weil, 1999). Fertilizers applied to golf courses are believed to be responsible for some $\mathrm{P}$ that enters surface water because golf courses are frequently found in areas adjacent to surface water (Christians, 1996).

A quick, reliable method of determining $\mathrm{P}, \mathrm{K}, \mathrm{Ca}$, and $\mathrm{Mg}$ concentrations of turfgrass would be a valuable asset, allowing turfgrass managers to apply fertilizers on a per need basis and avoid excessive fertilization. Objectives of this study were to evaluate the reliability of NIRS in determining $\mathrm{P}, \mathrm{K}, \mathrm{Ca}$, and $\mathrm{Mg}$ concentrations in bermudagrass.

\section{Materials and Methods}

Tissue samples were collected from golf courses throughout central and southern Florida. Sixty tissue samples were collected from golf course putting greens, tees, and
NIRS or by another procedure, as they are not consumed (Marten et al., 1985). x C. transvaalensis Burtt Davy] $\left(r^{2}=0.92\right)$ (Rodriguez and Miller, 2000). Advantages of preparation procedures. Scanning a sample typically takes $<3$ min. Sample preparation usually only involves drying and pulverizing, Table 1. Mean, standard deviation, and coefficient of determination for wet chemistry and NIRS values for 'Champion', 'FloraDwarf', 'Tifdwarf', and 'Tifway' bermudagrass samples collected from Florida golf courses.

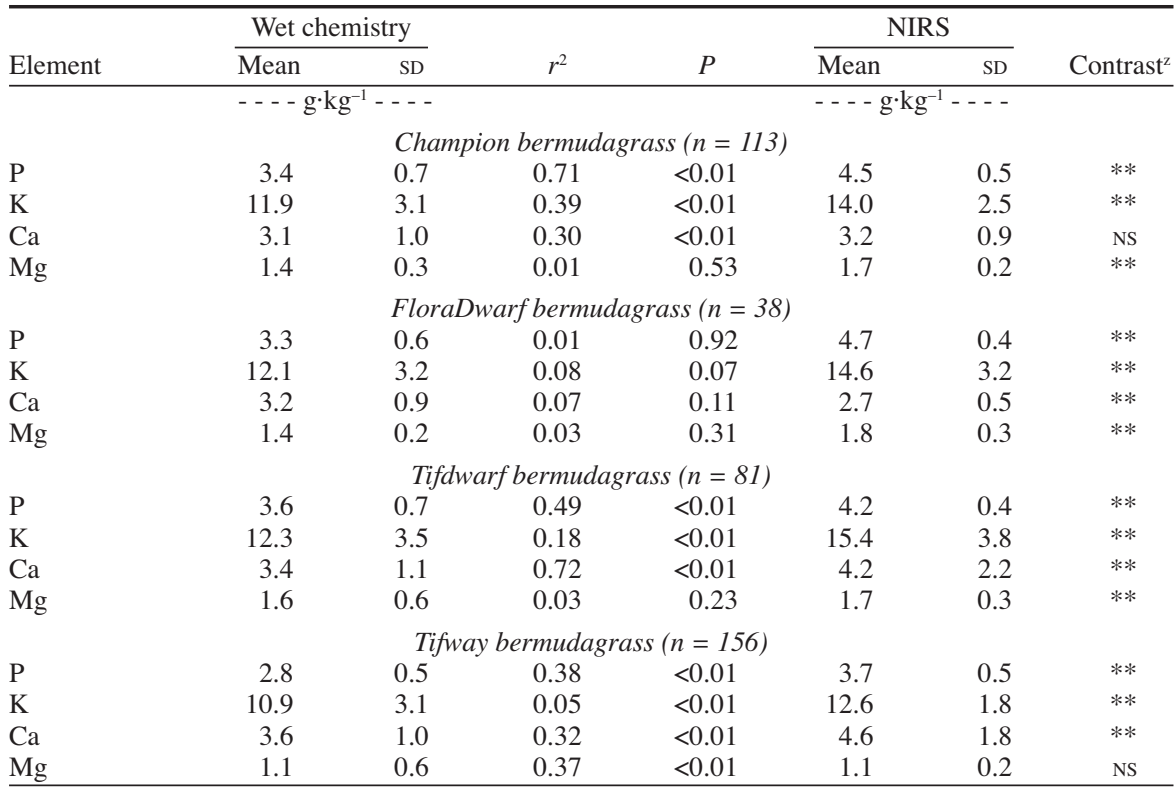

${ }^{2}$ Obtained by running single-degrees-of-freedom contrast to compare mean wet chemistry and NIRS values. 
fairways in the Gainesville to Tampa area. An additional 346 samples were collected by Toro representatives south of Tampa. Eighteen samples were discarded due to inadequate material for analysis, leaving 388 samples to test. The samples were obtained from a cross section of courses to ensure a range in nutritional levels and different cultivars. This was necessary to determine the influence of tissue nutrient concentration and cultivar on NIRS analysis. Nutrient values measured with wet chemistry techniques in this study ranged from deficient to sufficient according to sufficiency ranges reported by Jones et al. (1991). It was not known if NIRS is a more accurate predictor at particular nutrient concentration range or by cultivar.

Tissue samples were obtained immediately after mowing by collecting clippings from catch baskets attached to greens mowers. Clippings were placed in whirlpacks, sealed, labeled, and placed in a refrigerator. Packs were labeled according to course, date, location on course, and cultivar. About $250 \mathrm{~mL}$ of deionized rinsed clippings were placed on paper plates and dried in a $1000-\mathrm{W}$ microwave oven for $6-8 \mathrm{~min}$. Dried samples were ground in a cyclone mill (Udy Sample Mill; Udy Corp., Fort Collins, Colo.) to pass through a 1.0-mm screen. Dried samples were placed into sample cups, and loaded into a NIRS scanning instrument (model 5000; Foss NIR Systems, Silver Spring, Md.). A software package installed on an accompanying computer predicted tissue nutrient concentration for each sample based on spectral data (Toro Diagnostic Software Ver. 2.4; The Toro Co., Bloomington, Minn.). Following NIRS analysis, the samples were removed from the cups and prepared for Mehlich-1 extractable elemental analysis (Hue and Evans, 1986). Plant extracts were analyzed for P, K, Ca, and $\mathrm{Mg}$ using an Inductively Coupled Argon Plasma spectrophotometer (ICAP 9000; Jarrel-Ash, Franklin, Mass.). Data were analyzed using SAS General Linear Model procedure and correlation analysis (SAS Inst., 1987). Regression analysis data were plotted using SigmaPlot 2000 (SPSS Inc., 2000).

\section{Results and Discussion}

Location on the golf course (tees and fairways vs. greens) dictates the necessary turf growth habit and morphological characteristics required. For this reason differences due to location may be due to cultivar and managements influences. Due to desired turf quality, mowing intensity, and use, golf greens generally receive the highest yearly fertilizer rates on a golf course, followed by tees, and then fairways (McCarty, 2001). Positive correlations between NIRS and wet chemistry were found for some cultivar and nutrient combinations. Due to differences in cultivars, correlation analysis within cultivars were analyzed separately.

NIRS-P leaf tissue concentrations were higher than wet chemistry concentrations for 'Champion', 'FloraDwarf', and 'Tifdwarf' bermudagrass (Table 1, Fig. 1) across the measured range. However, there was a positive

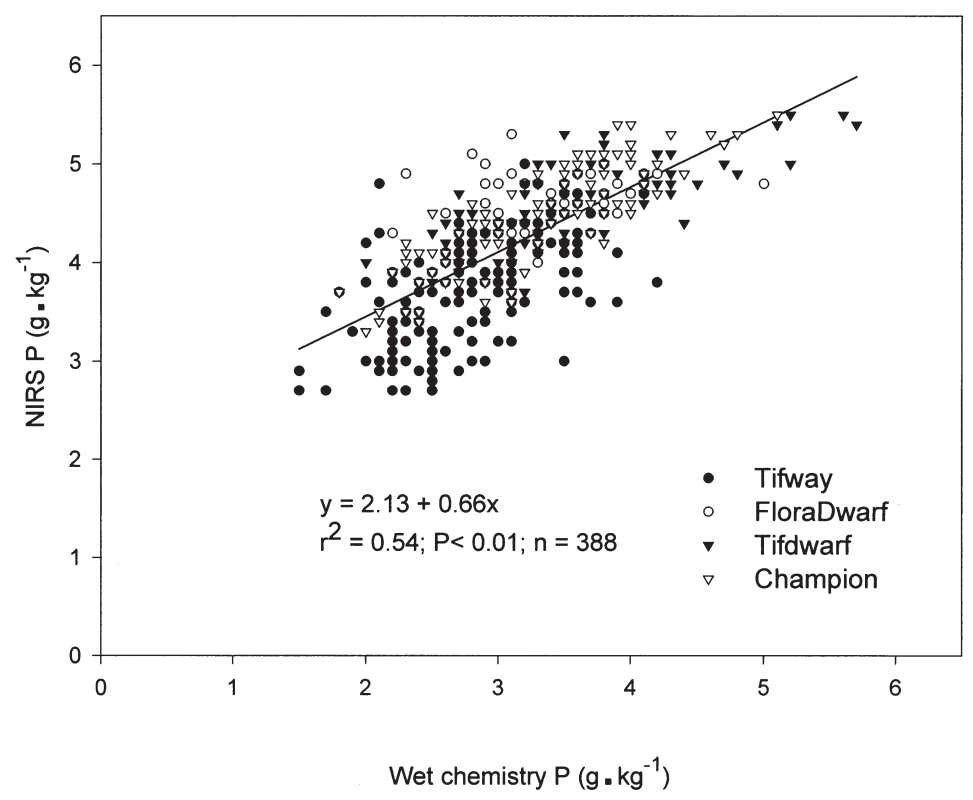

Fig. 1. Relationship between NIRS and wet chemistry leaf tissue P concentration for bermudagrass samples analyzed in golf course study.

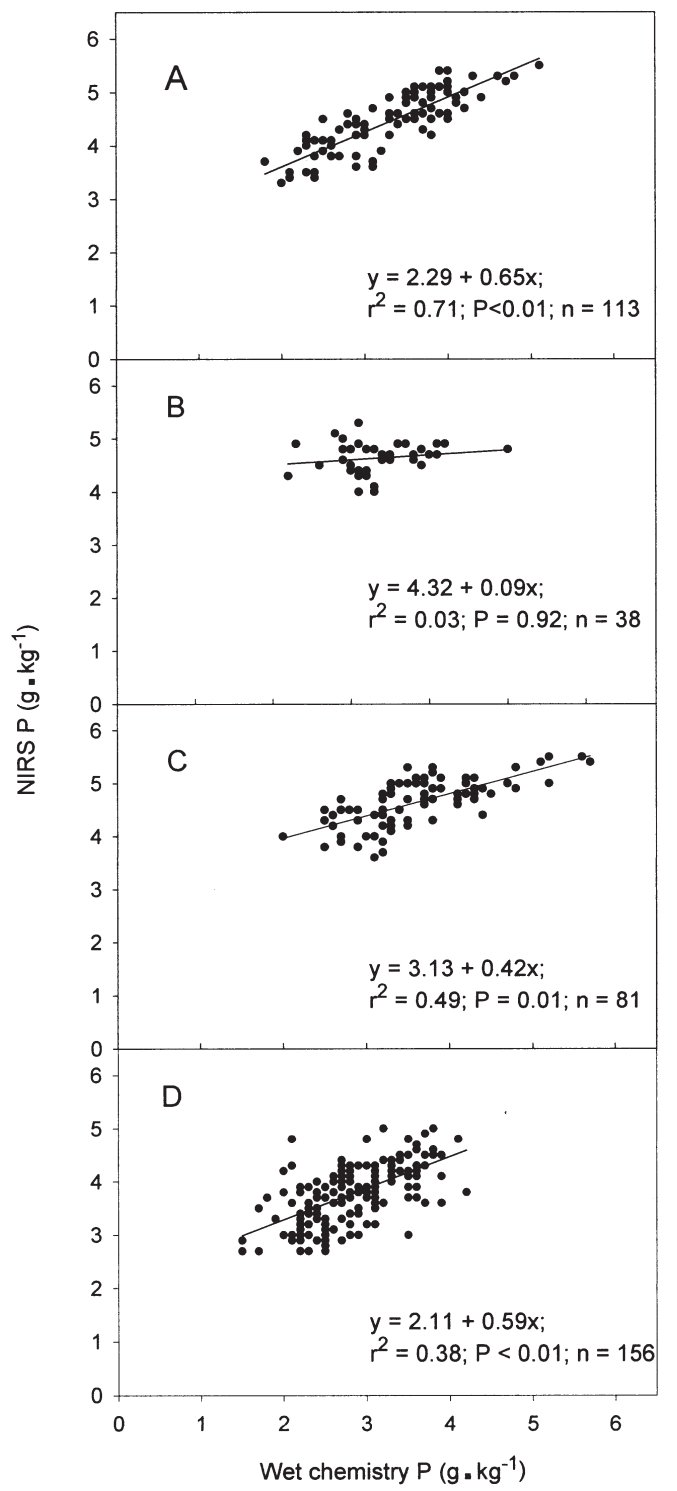

Fig. 2. Relationship between NIRS and wet chemistry leaf tissue P concentration for 'Champion' (A), 'FloraDwarf' (B), 'Tifdwarf' (C), and 'Tifway' (D) bermudagrass samples. 
correlation between NIRS and wet chemistry $\mathrm{P}\left(r^{2}=0.71\right.$, slope $=0.65 ; r^{2}=0.49$, slope $=$ 0.42 ), for 'Champion' and 'Tifdwarf' bermudagrass, respectively (Fig. 2). There was not a correlation between NIRS and wet chemistry $\mathrm{P}$ in 'FloraDwarf' bermudagrass (Table 1). This may be attributed to a greater number of samples with reflectance spectra more similar to 'Champion' and 'Tifdwarf' than 'FloraDwarf' being used in developing the master equation (Rodriguez and Miller, 2000). This lack of correlation may have also been exacerbated by the fewer number of 'FloraDwarf' samples (38) evaluated in this study; despite the concentration range measured for 'FloraDwarf' being similar to 'Tifway' ( $2.7 \mathrm{~g} \cdot \mathrm{kg}^{-1}$ units).

NIRS-K leaf tissue concentrations were higher than wet chemistry $\mathrm{K}$ for all cultivars analyzed (Fig. 3). Although there was a positive correlation for 'Champion' $\left(r^{2}=0.39 ; P<\right.$ $0.01)$, 'FloraDwarf' $\left(r^{2}=0.08\right)$ and 'Tifdwarf' $\left(r^{2}=0.18 ; P<0.01\right)$, precision was not sufficient to be useful (Table 1). NIRS-K predictions may produce results suggesting leaf tissue $\mathrm{K}$ concentrations are sufficient when a $\mathrm{K}$ application may be beneficial. Clark et al. (1987) reported NIRS may be able to predict certain cation concentrations due to their association with organic bonds. Potassium, unlike other elements, does not combine with other elements to form plant components such as protoplasms, fats and cellulose (Sartain, 1999). Thus, tissue K may be more difficult to detect by NIRS.

Regression analysis of NIRS-Ca vs. wet chemistry $\mathrm{Ca}$ across all the cultivars only accounted for $40 \%$ of the variability, but had a slope of nearly 1.0 (Fig. 4). Analysis with specific cultivars indicated NIRS and wet chemistry $\mathrm{Ca}$ concentrations were similar for 'Champion' bermudagrass. NIRS-Ca predictions were positively correlated with wet chemistry concentrations $\left(r^{2}=0.72\right.$, slope $=$ $1.78)$ in 'Tifdwarf'; however, NIRS-Ca concentrations were higher than wet chemistry levels (Table 1). Due to differences in NIRS correlations based on cultivars, developing cultivar-specific equations should improve NIRS reliability. Previous research on species-specific equations improved correlations compared to generalized equations (Rodriguez and Miller, 2000). In studies reported by Rodriguez and Miller (2000), an equation developed using cool-season and warm-season grasses had a correlation of $r^{2}=0.76$ and a slope of 0.8 , whereas an equation developed with only bermudagrasses (warm-season species) had a correlation of $r^{2}=0.92$ and a slope of 1.0 between wet chemistry $\mathrm{N}$ analysis and NIRS predictions.

Regression analysis of NIRS-Mg vs. wet chemistry $\mathrm{Mg}$ across all cultivars indicated low accuracy and low precision (Fig. 5). NIRS$\mathrm{Mg}$ predictions for putting green samples were higher than wet chemistry predictions (Table 1). This was not surprising since the cultivars generally found on greens ('Champion', 'FloraDwarf', and 'Tifdwarf') also had higher NIRS-Mg than wet chemistry. However, NIRS-Mg was similar to wet chemistry $\mathrm{Mg}$ for samples collected from fairways and tees
Table 2. Mean, standard deviation and coefficient of determination for wet chemistry and NIRS samples collected from fairways, tees, and greens. All fairway and tee samples were 'Tifway' bermudagrass.

\begin{tabular}{|c|c|c|c|c|c|c|c|}
\hline \multirow[b]{2}{*}{ Element } & \multicolumn{2}{|c|}{ Wet chemistry } & \multirow[b]{2}{*}{$r^{2}$} & \multirow[b]{2}{*}{$P$} & \multicolumn{2}{|c|}{ NIRS } & \multirow[b]{2}{*}{ Contrast $^{\mathrm{z}}$} \\
\hline & $\overline{\text { Mean }}$ & $\overline{\mathrm{SD}}$ & & & Mean & 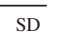 & \\
\hline & \multicolumn{2}{|c|}{$-\cdots \mathrm{g} \cdot \mathrm{kg}^{-1} \cdots$} & & & \multicolumn{2}{|c|}{$-\cdots \mathrm{g} \cdot \mathrm{kg}^{-1}-\cdots$} & \\
\hline \multicolumn{8}{|c|}{ Fairway-collected $(n=89)$} \\
\hline $\mathrm{P}$ & 2.8 & 0.5 & 0.19 & $<0.01$ & 3.7 & 0.5 & ** \\
\hline $\mathrm{K}$ & 10.9 & 3.0 & 0.01 & 0.39 & 12.1 & 1.3 & ** \\
\hline $\mathrm{Ca}$ & 3.9 & 1.1 & 0.34 & $<0.01$ & 5.1 & 2.1 & ** \\
\hline $\mathrm{Mg}$ & 1.2 & 0.5 & 0.19 & $<0.01$ & 1.2 & 0.2 & NS \\
\hline \multicolumn{8}{|c|}{ Tee-collected $(n=67)$} \\
\hline $\mathrm{P}$ & 2.8 & 0.6 & 0.59 & $<0.01$ & 3.9 & 0.6 & ** \\
\hline $\mathrm{K}$ & 10.8 & 3.4 & 0.13 & $<0.01$ & 13.4 & 2.2 & ** \\
\hline $\mathrm{Ca}$ & 3.4 & 0.9 & 0.16 & $<0.01$ & 4.0 & 1.1 & ** \\
\hline $\mathrm{Mg}$ & 1.2 & 0.9 & 0.58 & $<0.01$ & 1.2 & 0.3 & NS \\
\hline \multicolumn{8}{|c|}{ Green-collected $(n=232)$} \\
\hline $\mathrm{P}$ & 3.5 & 0.8 & 0.33 & $<0.01$ & 4.5 & 0.6 & ** \\
\hline $\mathrm{K}$ & 12.0 & 3.3 & 0.16 & $<0.01$ & 14.5 & 3.1 & $* *$ \\
\hline $\mathrm{Ca}$ & 3.2 & 1.0 & 0.35 & $<0.01$ & 3.6 & 1.1 & $* *$ \\
\hline $\mathrm{Mg}$ & 1.5 & 0.4 & 0.01 & 0.07 & 1.7 & 0.2 & $* *$ \\
\hline
\end{tabular}

${ }^{2}$ Obtained by running single-degrees-of-freedom contrast to compare wet chemistry and NIRS means for each element.

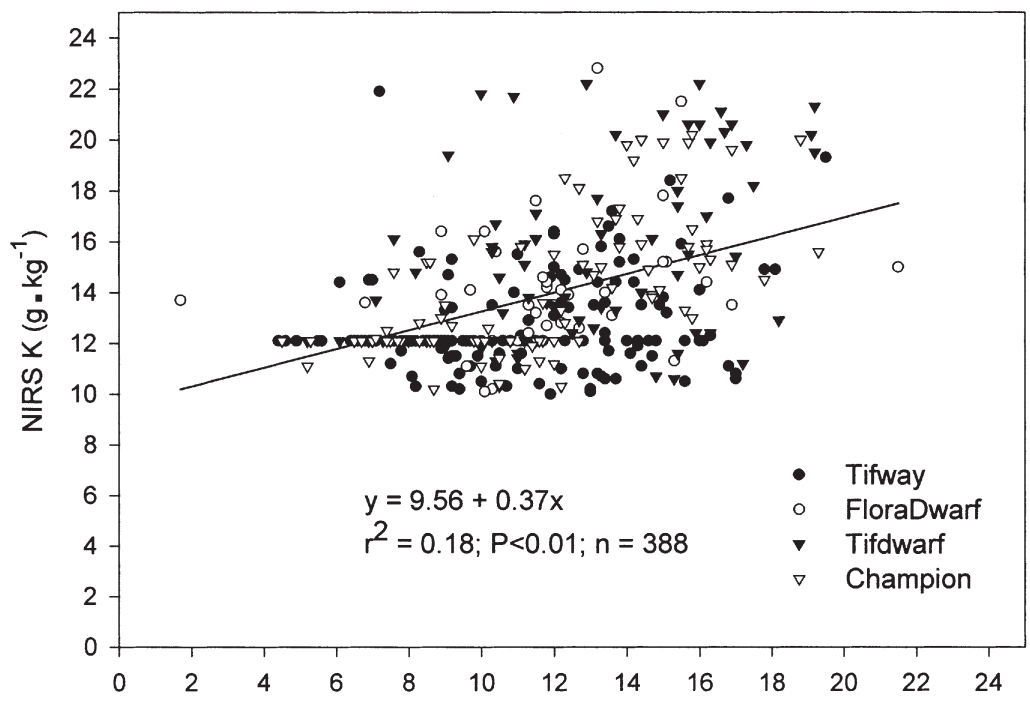

Wet chemistry $\mathrm{K}\left(\mathrm{g} \cdot \mathrm{kg}^{-1}\right)$

Fig. 3. Relationship between NIRS and wet chemistry leaf tissue K concentration for bermudagrass samples analyzed in golf course study.

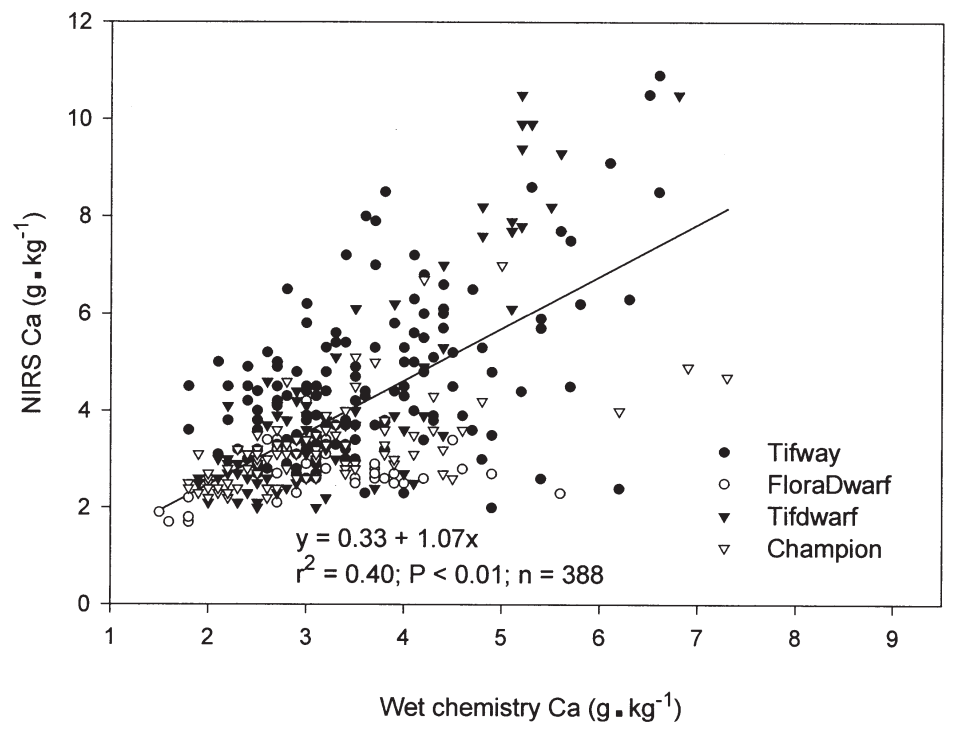

Fig. 4. Relationship between NIRS and wet chemistry leaf tissue Ca concentration for bermudagrass samples analyzed in golf course study. 


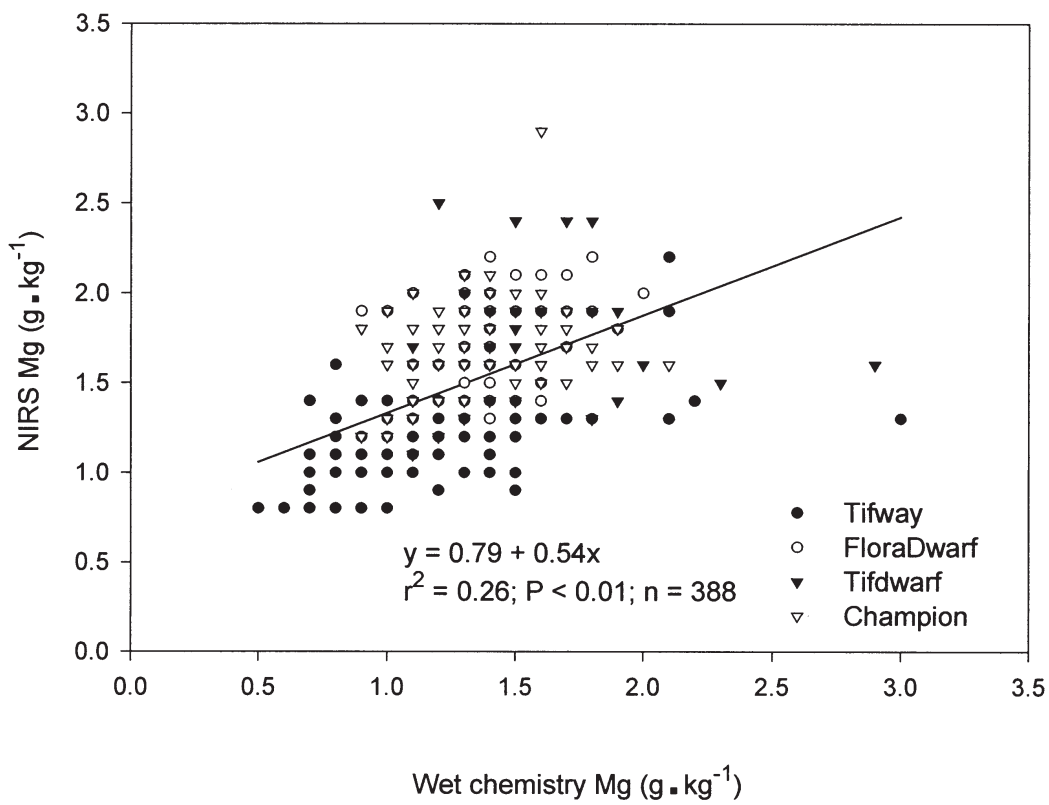

Fig. 5. Relationship between NIRS and wet chemistry leaf tissue Mg concentration for bermudagrass samples analyzed in golf course study.

(Table 2). Tee and fairway samples were 'Tifway', indicating NIRS may be more reliable in predicting $\mathrm{Mg}$ content in this cultivar.

NIRS-P, K, and Ca leaf tissue concentrations were higher than wet chemistry concentrations on samples collected from tees and fairways (Table 2). NIRS-P levels were positively correlated with wet chemistry $\left(r^{2}=\right.$ 0.59) for samples collected from golf course tees. A mean NIRS-P prediction of $3.9 \mathrm{~g} \cdot \mathrm{kg}^{-1}$ was higher than the mean wet chemistry level of $2.8 \mathrm{~g} \cdot \mathrm{kg}^{-1}$. Like NIRS-K analysis, NIRS-P $\left(r^{2}\right.$ $=0.38$ and slope $=0.59)$ may indicate sufficient tissue concentration in 'Tifway' tissue when a $P$ application may be beneficial. Developing a calibration equation to lower $\mathrm{P}$ predictions in 'Tifway' may improve reliability.

The bermudagrass-specific equation used in this study did not produce $r^{2}$ values as high as those found by Clark et al. (1987) for minerals in tall fescue (Festuca arundinacea Schreb.) and wheatgrass (Agropyron sp.). This study indicates that NIRS reliability depends on grass and cultivar. Nutrient content ranges (using wet chemistry) were broad and fell in the low (deficient) to upper end of the medium sufficiency range expected for bermudagrass
(Jones et al., 1991). NIRS consistently over predicted $(15 \% \pm 9)$ across the range sampled. Although results for certain cultivars were positively correlated, precision was not sufficient to be useful. NIRS-P, K, and Ca concentrations were consistently higher than wet chemistry levels. Thus, adjusting prediction equations to predict lower $\mathrm{P}, \mathrm{K}$, and $\mathrm{Ca}$ determinations should improve NIRS accuracy. NIRS does not seem to be as sensitive to tissue $\mathrm{K}$ as the other elements analyzed, with regression only accounting for $18 \%$ of the variability. It may be more difficult for NIRS to detect tissue K due to $\mathrm{K}$ not combining with other elements to form plant components. Mean NIRS-Mg concentrations were similar $\left(r^{2}=0.37\right)$ to wet chemistry in certain cultivars such as 'Tifway' but not other cultivars. Wet chemistry tissue $\mathrm{Mg}$ concentrations did not fluctuate as much as other elements, which may explain the lower $r^{2}$ values for NIRS-Mg $\left(r^{2}=0.26\right.$ across cultivars). In summary, the NIRS is a rapid means of evaluating tissue concentrations of $\mathrm{P}, \mathrm{K}, \mathrm{Ca}$, and $\mathrm{Mg}$ but the accuracy of prediction suggest that it would not be an effective management tool to monitor tissue nutrient content in bermudagrass.

\section{Literature Cited}

Brady, N.C. and R.R. Weil. 1999. The nature and properties of soils. Prentice-Hall, Upper Saddle River, N.J.

Christians, N.E. 1996. Phosphorous nutrition of turfgrass. Golf Course Mgt. 64(2)54-57.

Clark, D.H., H.F. Maryland, and R.C. Lamb. 1987. Mineral analysis of forage with near infrared reflectance spectroscopy. Agron. J. 79:485-490.

Fox, R.H., J.S. Shenk, W.P. Piekielek, M.O. Westerhaus, J.D. Toth, and K.E. Macneal. 1993. Comparison of near-infrared spectroscopy and other soil nitrogen availability quick tests for corn. Agron. J. 85:1049-1053.

Hue, N.V. and C.E. Evans. 1986. Procedures used for soil and plant analysis by the Auburn University Soil Testing Laboratory. Dept. of Agron. and Soils. Dept. Ser. 106. Auburn Univ., Auburn, Ala.

Jones, J.B., Jr., B. Wolf, and H.A. Mills. 1991. Plant analysis handbook. Micro-Macro Publishing, Athens, Ga.

Marten, G.C., J.S. Shenk, and F.E. Barton II (eds.). 1985. Near infrared reflectance spectroscopy (NIRS): Analysis of forage quality. Agr. Hdbk. No. 643, U.S. Govt. Print Office, Washington, D.C.

McCarty, L.B. 2001. Developing turf fertilizer programs. p. 236-249. In: L.B. McCarty (ed.). Best golf course management practices. Prentice Hall, Upper Saddle River, N.J.

Miller, G.L. 1999. Potassium application reduces calcium and magnesium levels in bermudagrass leaf tissue and soil. HortScience 34:265-268.

Murphy, J.A. 1993. Near-infrared reflectance spectroscopy to quantify leaf nitrogen concentration in turfgrass, p. 162. In: Agron. abstracts. ASA, Madison, Wis.

Nus, J.L., N.E. Christians, and K.L. Diesburg. 1993. High phosphorous applications influence soilavailable potassium and Kentucky Bluegrass copper content. HortScience 28:639-641.

Rodriguez, I.R. and G.L. Miller. 2000. Using near infrared reflectance spectroscopy to schedule nitrogen applications on dwarf-type bermudagrasses. Agron. J. 92:423-427.

Sartain, J.B. 1999. Potassium nutrition for bermudagrasses. Golf Course Mgt. 67(12)54-57.

Sartain, J.B. and A.E. Dudeck. 1982. Yield and nutrient accumulation of Tifway bermudagrass and overseeded ryegrass as influenced by applied nutrients. Agron. J. 74:488-491.

SAS Institute. 1987. SAS user's guide: Statistics. $6^{\text {th }}$ ed. SAS Inst., Cary, N.C.

SPSS Inc. 2000. SigmaPlot 2000 users guide. SPSS Inc., Chicago. 